草刈り作業によって生じた女性にみられる振動作業について

\title{
○櫻井忠義（日体大 ・健康科学）
}

[はじめに］母体を守る観点から、多くの職場では基 発に例示された振動工具を使用する作業に女性を従 事させることは制限され、もつぱら振動作業は男子が 行い、付帯作業に女性が加わる程度であったと考えら れる。最近、林業や建設業での振動工具使用者、主と して草刚り作業に従事する女性がみられる。土木員と して振動作業（草刈り）に就業し、現在まで長期間に 渡って草刚り機等を使用してきた女性達の振動作業 事例を経験した。その作業状况、障害、作業に出た家 庭状况の特徽が見られた。

[作業状況] 現在の年齢は 50 歳から 68 歳の主婦 23 名で、土木員として振動工具を使用した期間は 11 年 から 21 年になる。主な使用工具は手持ち、または工 ンジン部を背負う型の草刚り機で、道路周囲の草刚作 業を行う。溝工事、舗装工事の折はセメント描拌にバ イブレーターを、舗装時にはランマーを使用する。草 刈り機の使用時間は2月から9月にか计ては一月に 18 日から 23 日使用し、10月より 1 月にか计ては一月の 使用日が 20 日以下で、 15 日から 20 日になる。作業 日にはほぼ毎日草杊機を使用し、一日に $3 \sim 4$ 時間使 用する。バイブレーターやランマーは月に 3〜 5日で、 日に 0.5 時間ほど使用していた。就業時間は午前 8 時 から午後 5 時までで、草刚り作業以外は工事の付帯作 業を行う。使用草刚り機の振動は手持ち部分で主成分 80〜125Hz を中心とする 130〜 140dB の大きさを持 ち、背負い型では肩の部分でも $130 \mathrm{~dB}$ を越す振動を 有している。総重量は 15〜19kg であった。

[雇用条件、生活状況] 職場では健康保険、雇用保険、 厚生年金がかけられ、個人でも生命保険をかけていた。 雇用は長期雇用であるが、給与は日給制で、仕事日に 応じて月毎に支払われ、現在で 10〜12 万円になる。 職場へは軽トラックで 10〜15 分の比較的住家に近い 職場である。職場で特殊健康診断が行われたことはな い。それぞれの家庭が 3反〜 8反の田畑を持ち、家族 は勤めに出る夫と、子供 1 ～5人で、仕事にでた理由 は子供の養育費、修学費を得るためである。

[健康障害の特徴] 手指、腕手のしびれ、指、手首、 肘の痛み、手の泠え、手のひらの汗異常、耳鳴り、寝 つきの悪さ、局こりが共通症状である。その他に腰の
痛み、疲れやすさ、手指の動きの悪さ、握る力が落ち たと共に、生活上の訴えが多く、細かい手作業の困難 さ、服のボタンのはめ難さ、食事や洗い物のときに茶 碗箸を落とす、手指の動きが悪くて家事がつらい、危 険なことがあるなどを訴えた。レイノー現象は 4 名に みられた。

尿検查、血液検查に著変はみられないが、8名に高 脂血症がみられた。振動作業に伴う障害検査では末梢 循環障害 (皮膚温低下、指尖容積脈波波高低下、冷水 負荷検查による回復遅延など）、末梢神経障害（指の 触覚、痛覚、振動覚等の知覚鈍麻)、運動機能障害 (握 力、ピンチ力低下、タッピング能低下、肘手首指関節 可動域制限）、骨関節障害（レントグン写真にて时、 手首、指関節の変形性変化）がみられた。

聴力検查で高音域に聴力低下を認める者 9 名で、 2 名に胸部XPに軽度の粒状影がみられた。振動のみな らず騒音や粉應、肉体労働に伴う障害が見られた。ま た、頚椎の変形性変化を認める者はエンジン背負型の 草刚り機使用者 4 名のうちの 3 名に、内 1 名には後方 すべりがみられた。既往に外傷などがないことから背 負い型の草刈り機による振動の影響が頝椎変化の原 因と考えられた。手指のDIP 関節 (指の末節の遠位関 節）、PIP 関節（指の中節と基節の間の近位関節）の 唕湰がみられ、レントゲン写真で DIP、PIP の骨棘、 関節腔隙の狭小化、脱臼様変化が 13 名に認められた。

[まとめ] 女性の振動作業への従事、障害がみられる ようになった。農家主婦の職業性疾患䍜患の経緯であ る。夫は農家のみでは家族の生計を立てられずに仕事 に出かけ、今まで田畑を耕していた主婦も子供の養育 費、学費、生計のために夫に続いて近隣の土木工事に 出かけることになり、簡便な労㗢力として重宝されて いる。賃金は日給月給制で 9 時間拘束の割には極めて 低く抑えられている。作業者側にも使用者側にも女性 と男性との賃金差を当然であると言う認識があり、農 家で食べ物に困らないことがその状況を許容すると いう地域性がある。振動障害に加え、騷音、粉應、肉 体労働に伴う障害がみられる。また、使用草刈り機の エンジン部を背中に背負うという機器使用法に関わ って発生したと見られる変形性頝椎症がみられた。 